SOCIETY OF

ARCHITECTURAL

HISTORIANS

Review

Reviewed Work(s):

The Fort at Dereağzi and Other Material Remains in Its Vicinity: From

Antiquity to the Middle Ages

by James Morganstern

Review by: Scott Redford

Source: Journal of the Society of Architectural Historians, Vol. 54, No. 3 (Sep., 1995), pp. 370-371

Published by: University of California Press on behalf of the Society of Architectural Historians

Stable URL: https://www.jstor.org/stable/991010

Accessed: 05-09-2019 16:34 UTC

JSTOR is a not-for-profit service that helps scholars, researchers, and students discover, use, and build upon a wide range of content in a trusted digital archive. We use information technology and tools to increase productivity and facilitate new forms of scholarship. For more information about JSTOR, please contact support@jstor.org.

Your use of the JSTOR archive indicates your acceptance of the Terms \& Conditions of Use, available at https://about.jstor.org/terms

Society of Architectural Historians, University of California Press are collaborating with JSTOR to digitize, preserve and extend access to Journal of the Society of Architectural Historians 
correct that such overbuilding would result in energy savings, although rebuildings in residential compounds probably also reflected space limitations in the thickly settled area of the Copan river floodplain. However, it is unlikely that "energy savings" were the primary reason for rebuildings. More likely, rebuildings were placed above preexisting structures primarily because they marked the places of particularly important shrines whose location could not be altered. This is well attested at Copan, where earlier prototypes of the Main Ballcourt and Structure 22 underlie the latest buildings and were clear models for them. Even in the case of domestic structures, a desire to rebuild on "hallowed ground" played a role, as demonstrated in Patricia
A. McAnany's book, Living with the Ancestors: Kinship and Kingship in Ancient Maya Society (1995).

Abrams's efforts to document the energy expended on buildings at Copan is an attempt to demystify the Maya and to demonstrate that to the extent that such buildings convey the message that their builders wielded great coercive power, that message may be highly untrustworthy. However, the differences in scale and quality among residential structures more likely do reflect the differential "authority" of their occupants. As his section "Stratification and the Role of Architecture" suggests, that authority was grounded in kinship and lineage obligations, administrative duties, and ritual responsibilities, with particular emphasis on the ritual role of the K'ul Ahau or Divine King.

Abrams's book represents one of the most intensive, carefully documented, and successful efforts yet to interpret how the Maya constructed their sites based on anetic, or outsider's perspective. It is an important counterpoint to the work of scholars such as Linda Schele, David Freidel, Wendy Ashmore, Clemency Coggins, William Fash, and others, whose studies emphasize why the Maya built environment took the form it did, based on the Maya's own worldview. Those interested in understanding ancient Maya architecture in its social and cultural context must consider both viewpoints.

- Jeff Karl Kowalski

Northern Illinois University

\section{FROM ANTIQUITY TO BAROQUE}

James Morganstern, ed.

\section{THE Fort AT DEREaǦzI AND}

\section{Other Material Remains In ITS} VICINITY: FROM ANTIQUITY TO THE Middle AGes

German Archaeological Institute, Istanbul, Istanbuler Forschungen, vol. 40; Tübingen: Ernst Wasmuth, 1993, xli +181 pp., 67 illus. DM 78. ISBN 3-8030-17610.

This volume is the companion to the editor's publication The Byzantine Church at Dereağzi and its Decoration (Istanbuler Mitteilungen Beiheft 29 [1983]). It is the final publication of four seasons of survey work at the site of Dereağzi in southwestern Turkey (historic Lycia) undertaken by a team of Americans and Europeans under the directorship of Professor Morganstern. The text is largely in English, with some sections in German.

The volume begins with a historical survey of Lycia by Clive Foss. The main body of the text concerns the architecture of the fortress, which the authors conclude was erected in the first half of the fourth century B.C. and rebuilt sometime in the late ninth or early tenth century, in the Middle Byzantine period, contemporary with the construction of the impressive church that was the subject of the initial volume on Dereağzi. Next, a concise sec- tion on the communication and water system of the area, by David French, is followed by Robert Bridges's presentation of the Lycian rock-cut tombs found there. Morganstern and others then take up remaining evidence of habitation, including ceramics, coins, and architectural remains north of the fortress.

This volume is impressive in several regards. First, the quality of the photographs and drawings is very high: they are clear, precise, and consistent and document well the points made in the text. Second, the authors are scrupulous not to force conclusions from the sometimes scrappy evidence of a survey, but utilize every means available, including epigraphy, numismatics, historical geography, carbon 14 dating, and a thorough reading of the sources, to arrive at their conclusions.

Third and most important, theirs is a contextual approach. Scrupulous documentation of all of the surviving surface material remains should be an aim of all architectural and archaeological publications, but above all at Dereağzi. There the essential question for over a century has been one of context. What are the remains of a Middle Byzantine church, impressive for its size, plan, and decoration, doing in provincial Anatolia some fourteen miles from the church of St. Nicholas at Myra (present-day Demre)? Speculation on the date and function of the church at Dereağzi has occupied many Byzantine architectural historians over the years. After having concentrated on it in his first volume, Morganstern rightly concluded that a full presentation of the surrounding material remains was essential for an understanding of the history of occupation in the area.

As a result, we have a thorough discussion of the original Lycian fortress, including a fragmentary relief found there, and a presentation of the Lycian rock-cut tombs that is a model of exposition and presentation. A Lycian inscription on one of the tombs is analyzed, and comparative material from neighboring sites is presented by Bridges, Wolfgang Wurster, Jürgen Borchhardt, and Günter Neumann. Fragmentary remains of early Byzantine architectural sculpture from the fortress complement similar material presented in the first volume, but the main thrust of the Byzantine section is the Middle Byzantine period. Evidence from carbon 14 analysis of wall mortar, inscriptions, and building materials and techniques lead Morganstern to argue for a Byzantine reoccupation and rebuilding of the Lycian fortress contemporary with the building of the church.

My one quibble with the presentation of the history of occupation at the site comes from the use of numismatic evidence. In my opinion, the integrity of an argument built on careful analysis of masonry, inscriptions, and other remains is partially sacrificed in 
the interest of completeness of presentation of the occupation sequence by overreliance on coins. In the discussion of occupation outside two main Lycian and middle Byzantine periods, too much weight is given to the presence or absence of a handful of coins, most of which, in any case, were not found by the survey team itself but presented by villagers in the area. This evidence should not have been accorded such importance, especially in the conclusion. But this is a minor objection to an otherwise careful weighing of evidence.

In his conclusion, Morganstern relates the Middle Byzantine reoccupation of the site of Dereağzi to the reorganization of Byzantine maritime defenses in Lycia and neighboring Pamphylia in the ninth and early tenth centuries. With a reinvigorated military presence in the region would have come the need for more and better defense, more food for coastal settlements, and timber from the mountains for the fleet. Since Dereağzi controlled one route of access to the interior and sources of timber and grain, the rebuilding of the fort at this time comes as a logical outcome of this increased activity.

Too often, buildings of architectural significance like the church at Dereağzi are the subject of studies that treat them in isolation from their surroundings. It is to the great credit of the authors that they have insisted on placing Dereağzi well and firmly in its historical, architectural, and topographic context. This volume, as a result, is the natural companion to its predecessor and of interest to students of Byzantine and Lycian architecture. It presents a clear picture of one particular spot along Turkey's Mediterranean coast, adding a small but significant piece to ongoing efforts to track the settlement of this difficult but strategic site in the ancient and medieval periods.

This volume complements Foss's work on Byzantine fortifications elsewhere in Anatolia, Robert Edwards's publication of the fortifications of Armenian Cilicia (DOP, 1987), and Lyndley Vann's ongoing survey of the ancient harbors of Mediterranean Anatolia. Striking in many of these cases is the reoccupation and reuse of earlier sites and fortifications during the Middle Byzantine period, a practice that makes the use of masonry techniques as a dating tool notoriously difficult. Morganstern's emphasis on linking this inland site to coastal activity strikes this reader as correct, and, despite a paucity of source material, points to the need to examine the range of medieval fortifications along the coast in Lycia, Pamphylia, and Rough Cilicia. The detailed publication of the fort at Dereağzi provides important documentation for this area of investigation that is richer than medieval sources would indicate. - Scott Redford Georgetown University

\section{Christian Freigang}

\section{IMTTARE ECclesias NobILes: DIE KATHEDRALEN VON NARBONNE,} TOULOUSE UND RODEZ UND DIE NORDFRANZÖSISCH RAYONNANTGOTIK

\section{IM LANGUEDOC}

Worms: Wernersche Verlagsgesellschaft, 1992, 406 pp., 337 illus. DM 285. ISBN 3-884-6285-1.

In his essay of 1929, "Architecture," Georges Bataille wrote, "Architecture is the expression of the very soul of societies, just as the human physiognomy is the expression of individuals' souls." This comparison assumes particular relevance to a consideration of Gothic ecclesiastical architecture in southern France and, ultimately, lies at the heart of Christian Freigang's impressively dense study of the cathedral St.-Just-St.Pasteur of Narbonne and its contemporaries. During the half century between 1270 and 1330, a generation of churches, most spectacularly represented by the cathedrals of Narbonne, Toulouse, Rodez, and Carcassonne as well as the Cistercian abbey of Valmagne, changed the face of Languedocian architecture through the adoption of the structural and aesthetic package of the rayonnant style of northern France. Verticality, elaborate linearity, and expansive glazing replaced the well-established regional tradition of broad spaces enclosed by heavy walls as the defining terms of elite architecture. But whose architectural visage is represented by the sheer, forty-meter-high walls of Narbonne or by the fragile glass box of Saint-Nazaire in Carcassonne: that of the bishop, the king, the community, or the master mason?

Investigation of the mechanisms and significance of the stylistic coup embodied by the cathedrals of Narbonne, Toulouse, and Rodez leads to the issues of individual genius and power. The first centers on the "career" and architectural personality of Jean Deschamps. Mentioned as master mason of Clermont cathedral in 1248 and again at Narbonne in 1286, Jean has evolved during the past century of scholarship into something of a thirteenth-century Daedalus, for he has also been credited with the designs of the cathedrals of Limoges, Toulouse, Rodez, and Agen along with a handful of abbey and parish churches. The striking differences among these buildings becomes the measure of creative growth during a working life that spanned nearly a half century. Second, Jean's activity in Auvergne and Languedoc appears to ride the wave of expanding royal power in the south. In an explanation that resonates sympathetically against modern political situations, the new churches have been read as the tools of a "foreign" Capetian monarchy which, with the complicity of its ecclesiastical allies, imposed the rayonnant style as the symbol of its colonialist presence and the victory of orthodox Catholicism over local Cathar beliefs. It is to Freigang's credit that he rejects arguments that collapse southern French architecture into the oeuvre of one master or the consequence of a single historical circumstance and seeks instead to reconstitute the complex "bandwidth" of architectural possibilities within which each edifice is situated.

My remarks in this review can touch only a few salient aspects of Freigang's research, which brims with new information and insight. The comprehensive collection of documentary evidence, the rigor of archaeological analysis, and the international frame of reference establish Imitare Ecclesias Nobiles as a cornerstone upon which future study of late thirteenth- and early fourteenth-century architecture must be based. And it is hoped that this fresh look at the remarkable rayonnant buildings of Languedoc will spark complementary explorations into their liturgical and cultural aspects.

As the first order of business on his ambitious agenda, Freigang devotes half of the book to detailed building histories of Narbonne, Toulouse, and, to a lesser degree, Rodez. While the unflinching expository structure of documentary history, relative physical chronology based on formal description and analysis, and absolute construction chronology results in a multiplica- 